\title{
Parental Family Income and the Socioeconomic Attainment of Children
}

\author{
Martha S. Hill and Greg J. Duncan \\ Survey Research Center, Institute for Social Research, University of Michigan \\ Like others before us using different data, we find significant effects of parental \\ family income on the completed schooling and wage rates of adult children using \\ intergenerational data from the Panel Study of Income Dynamics. We explore \\ various hypotheses regarding these effects, finding substantial support for the \\ economic hypothesis that income, regardless of its source, is invested by parents \\ in their children; mixed support for the hypothesis that fathers serve as role \\ models for their sons; and no support for the welfare dependency hypothesis. \\ Rather than serving as positive role models, working mothers appear to have \\ significantly less successful sons. ๑ 1987 Academic Press, Inc.
}

Among the various components of the childhood environment thought to influence adult achievement, the income of the parental family occupies an uncertain position. Since parental income levels cannot be recalled reliably by children when they reach adulthood, that aspect of childhood is not typically included in studies that use retrospective data to estimate models of intergenerational socioeconomic attainment. ${ }^{1}$ When special efforts are made to measure parental income and include it in the models, it often turns out that income has statistically significant and substantively important effects on the subsequent attainment of children. These effects usually persist after one controls for differences in the more conventional measures of parental background, such as the education and occupational prestige of the parents.

Preparation of this paper was supported in part by a grant from the Ford Foundation. The authors contributed equally to the paper and are listed in an order determined by a random device. We are grateful for helpful comments from Linda Datcher-Loury, Dorothy Duncan, Nancy Gordon, Christopher Jencks, Gary Solon, Frank Stafford, Arland Thornton, and two referees. Requests for reprints should be sent to Greg J. Duncan, Survey Research Center, Institute for Social Research, P.O. Box 1248, Ann Arbor, MI 48106.

${ }^{1}$ An ingenious exception is Bielby and Hauser (1977), who use the test-retest reliability of reports of parental income from the 1973 Occupational Changes in a Generation study to adjust estimates of models that relate earnings to a set of parental background measures. 
The dearth of empirical knowledge about the role of income stands in marked contrast to the abundance of hypotheses about its importance. Economists' models of intergenerational attainment emphasize pooled parental family income, usually without differentiating among the sources of that income, as a crucial determinant of the parental "demand" for the attainment of children. Sociological explanations, on the other hand, tend to view income not so much as a resource available for enriching the child's environment, but as a reflection of certain underlying conditions or processes. For example, the labor income of the father or mother is believed to convey information about the role model provided by that parent. The receipt of welfare income may reflect the extent to which a household has adopted the counterproductive norms and values of a welfare "culture."

This article attempts to disentangle the role of parental income in the attainment process using intergenerational data from the Panel Study of Income Dynamics (PSID). Parents' own reports of the components of family income, averaged over the 3-year period when the child is between 14 and 16 years of age, provide reliable measurement for that period of parental family income from five sources: the father's work, the mother's work, assets, welfare programs, and all other sources. Hypotheses about the role played by these income components in the intergenerational attainment process are tested by relating them to children's own reports of their completed education and hourly earnings when they are between the ages of 25 and 27.

\section{THE EMPIRICAL IMPORTANCE OF PARENTAL FAMILY INCOME}

The most widely known attempt to incorporate parental income in an otherwise conventional model of socioeconomic attainment is that of Sewell and Hauser (1975), who based their estimates on a cohort of male high school seniors in Wisconsin. They found that the taxable income of parents had highly significant effects on the education and particularly on the earnings of their sons at about age 25. Little of the effect of parental income on earnings was mediated by education, attenuated by controls for other measures, or, as reported in Hauser and Daymont (1977), reduced when earnings were measured in the subsequent 6 years. The power of the income measure was impressive:

There can be little doubt that the association of socioeconomic background variables with son's earnings is due solely to the intergenerational effect of parents' income, while the latter cannot to any large extent be explained by the differing abilities, educational attainments, or occupational achievements of the sons of rich and poor families. (Sewell and Hauser, 1975:84)

Additional analysis of this sample and its female counterpart in Sewell et al. (1980) showed highly significant effects, for both sexes, of parental 
income on completed education, the status of first full-time jobs, and the status of jobs held some 18 years after high school graduation when these outcomes were regressed on a set of parental background measures. A replication study using the same general model with data from the Wisconsin sample, Project Talent and Explorations in Equality of Opportunity (EEO) in Jencks et al. (1983), also found significant effects of parental income on completed schooling and, with the exception of the Project Talent data, on earnings as well.

Behrman et al. (1980) review earlier work, usually based on even more specialized samples, that produced estimates, generally positive but modest in magnitude, of the correlation between parental income and offspring's earnings. Behrman and Taubman (1985) use the NAS-NRC twin sample of white men born during the years 1917-1927 and their sons and daughters to correlate a single-year (1980) measure of child's earnings and a singleyear (1974) measure of father's earnings. These estimates were also positive but small in magnitude.

Alwin and Thornton (1984) use data on a cohort of white children born in 1961 in the Detroit metropolitan area and living in intact families throughout childhood to relate various measures of parental background, including income and assets, to a set of educational outcomes. Unique to these data are background measurements at several points during childhood. They tested the effects of a measure combining income and assets, gathered in early and late childhood, on the amount of completed schooling (at age 18) and on whether the child was in a college preparatory program in high school, finding significant effects only for the early childhood measure of the income-asset variable.

Corcoran and Datcher (1981) and Kiker and Condon (1981) use PSID data to estimate attainment models similar to those of Sewell and Hauser. Corcoran and Datcher (1981) find that a single-year measure of total parental family income had positive and significant effects on the education, hourly earnings, and annual earnings of sons. Kiker and Condon (1981) find that 5-year average parental income had a positive and significant effect on the log earnings but not completed schooling of sons. Differences in sample definition, particularly the use of very young (age 19-22) household heads in the Kiker and Condon analysis, may account for the different findings.

Focusing more specifically on the influence of exposure to the singleparent situation while growing up, McLanahan (1985) and Shaw (1982) investigate family income as the source of single-parent effects on the educational attainment of children. Using PSID data for children of both sexes (McLanahan) and National Longitudinal Survey data for mature and young women (Shaw), they find strong, positive effects of parental income on high school retention rates for children from single-parent and two-parent homes. Furthermore, lowered parental income is found to 
account for a substantial share of a negative single-parent effect on educational attainment, especially among whites.

For our analysis we use data from the PSID, pooling three birth cohorts. The individuals in these cohorts were between the ages of 14 and 16 and living in their parental homes when they were observed in the early years of the panel, and they were observed again-either in their own households or still in their parental homes-between the ages of 25 and 27. The PSID provides a rich set of parental background measures, usually reported by the parents themselves, as well as two key outcome measures for the children: completed education and an average hourly wage rate, inflated to 1982 price levels. Education is reported for all children in the sample; hourly earnings are observed for the years between ages 25 and 27 during which the child worked at least 500 hrs. The restriction of the wage rate analysis to children with at least 500 work hrs in one of the 3 years raises the possbility of selection bias. Estimation using Heckman's (1979) procedure for correcting for selection bias did not substantially change any of the results presented below. We average parental family income, inflated to 1982 price levels, as reported by the family head or wife, over the 3-year period when the child is 14-16 years of age. A more detailed explanation of the sample selected for the analysis and a description of the variables are presented in an appendix.

With a few notable exceptions, the structure of the relationship between the background measures and completed education (Table 1, columns 2 and 5) and the natural logarithm of the hourly wage rate (Table 2, columns 2 and 5) is consistent with past research. ${ }^{2}$ This analysis, however, focuses on parental income. By itself, parental income (and its correlates) explains about one-fifth of the variance of completed education and less than onetenth of the variance of In wage rates. When evaluated at sample means, the four unadjusted coefficients imply that a $10 \%$ increase in parental income is associated with a 1.4 to $1.8 \%$ increase in schooling and In wage rates. These elasticities are similar in magnitude to those presented in the survey article of Becker and Tomes (1986). The addition of the other background measures reduces the estimated coefficients on parental family income and their implied elasticities by between one-third and one-half, but in every case the adjusted coefficient on the income measure is statistically significant at the $10 \%$ level, and in all but one case at the $1 \%$ level. ${ }^{3}$ Even after adjusting for differences in parental schooling and

${ }^{2}$ More detailed descriptions of the relationships between PSID background measures and children's attainments are presented in Corcoran and Datcher (1981). Most notable among the exceptions is the lack of association between the occupational prestige of the fathers and the attainments of their sons. During the early years of the PSID occupation was coded at the one-digit level, providing an exceedingly crude measure of the fathers' SEI.

${ }^{3}$ Roughly comparable regressions reported in Sewell et al. (1980) relating completed education to parental background measures for the Wisconsin sample produced similar 
all other background measures, a standard deviation increase in parental income for sons $(\$ 16,263$ in 1983 dollars) is associated with a 0.53 year increase in the sons' completed schooling and a $9.7 \%$ increase in their hourly earnings. The corresponding increases for daughters are 0.50 years of completed education and a $6.5 \%$ increase in hourly earnings. ${ }^{4}$

\section{ANALYSIS FRAMEWORK}

A family's income "package" is remarkably heterogeneous and conveys information not only about the resources a family has at its disposal but also about the structure and other potentially important attributes of that family. Families with working mothers, for example, may differ from other families in ways unrelated to the possible benefits provided by the mother's income itself. Working mothers may boost the labor market attainments of daughters by providing a positive role model. On the other hand, their absence from the household may reduce the time spent with the children and lead to less schooling for both daughters and sons. Children from families with income from welfare may benefit from the greater resources provided by that income, but may also be harmed by the dependence induced by repeated or prolonged contact with the welfare system. Since virtually all fathers worked, families with no labor income of the father are practically synonymous with families in which the father was absent from the household, and a variety of detrimental effects for children have been posited for their father's absence.

Hypotheses about the intergenerational attainment process have testable implications for these differing aspects of parental income. We shall demonstrate that many of the hypotheses can be tested with a model that disaggregates total income by source and also differentiates the effect on the attainment of children of the first dollar of a given income source

coefficients on parental income. They estimate that an additional $\$ 1000$ of annual parental taxable income averaged between 1957 and 1960 (when the children were about ages 1820) was associated with a 0.073 year increase in the completed schooling of the men in their sample and a $\mathbf{0 . 0 5 9}$ year increase in the schooling of the women. Adjustments for cost-of-living differences between the late 1950 s and early 1980 s would reduce those coefficients by two-thirds, making them somewhat smaller than the .033 and .031 coefficients on parental income reported in Table 1 for sons and daughters, respectively. One possible source of the remaining differences could be the truncation of the Sewell et al. educational attainment measure, with individuals failing to reach their senior year in high school omitted from the sample and the authors failing to adjust for the possible statistical complications of a truncated dependent variable. They also truncate parental income with a upper limit of $\$ 25,000$. This, too, could be a source of the differences in observed effects of parental income.

${ }^{4}$ The addition of measures of work experience and the child's own education to the wage rate regressions would undoubtedly reduce the explanatory power of parental income even more. We have not included these intervening measures in any of our analyses, because we seek structural estimates of the total effects of parental income rather than the direct effects operating independently of education and experience. 
and subsequent dollars from that source. Five income components are distinguished: the labor income of the father and mother, income from assets, income from cash assistance programs, and a catch-all category of all other income. A piecewise linear (spline) function for each of the five income components is fit, allowing for different slopes between the first dollar of each type and additional dollars beyond the first. Receipt of the first dollar usually conveys information about the structure or other potentially important characteristics of the household-such as father present, mother working, welfare recipient, or asset accumulation. Receipt of additional dollars of an income source conveys different information-about the total resources available to the household or, in some cases, about characteristics such as the strength of a role model or the extent of welfare dependence.

Under certain conditions, this division between first and subsequent dollars from a given source is the proper one for testing hypotheses about income from that source. The first-dollar variable controls for whether or not income from a given source was received, and the coefficient on subsequent dollars from that source measures the effect of those additional dollars on the attainments of children coming from families with that form of income. There is a potential for selection bias in these estimates if the process that produces families with income from a given source is related to the process by which that income affects the socioeconomic attainments of children. ${ }^{5}$ We argue below that for one hypothesis-regarding role models provided by working mothers-such bias may well exist, and we make the proper statistical adjustments to eliminate it.

There are some additional reasons, described in Section 4, for departing from this general framework for testing some of the hypotheses. Common to all specifications, including the spline model, are adjustments for contextual factors. Most theories about the effects of parental family income place that income in the broader context of other aspects of the parental family. We attempt to do this as well by including in our regressions the parental characteristics and environmental conditions listed in Tables 1 and 2.

\section{HYPOTHESES REGARDING THE ROLE OF PARENTAL FAMILY INCOME}

It is useful to divide hypotheses regarding intergenerational attainment into those based primarily on economic factors and those motivated by sociological or social-psychological considerations. Common to the economic models is an emphasis on income itself as an economic resource

\footnotetext{
${ }^{5}$ More specifically, there will be selection bias if the error terms in these two equations are correlated.
} 
TABLE 1

Effects of Family Income and Various Background Measures on the Completed Education of Children ${ }^{a}$

\begin{tabular}{|c|c|c|c|c|c|c|}
\hline \multirow[b]{2}{*}{$\begin{array}{l}\text { Total parental family } \\
\text { income in thousands }\end{array}$} & \multicolumn{3}{|c|}{ Sons } & \multicolumn{3}{|c|}{ Daughters } \\
\hline & $\begin{array}{l}.060^{* *} \\
(.006)\end{array}$ & - & $\begin{array}{l}.033^{* *} \\
(.007)\end{array}$ & $\begin{array}{l}.058^{* *} \\
(.006)\end{array}$ & - & $\begin{array}{l}.031^{* *} \\
(.007)\end{array}$ \\
\hline $\begin{array}{l}\text { Father's } \\
\text { education }\end{array}$ & - & $\begin{array}{l}.14^{* *} \\
(.03)\end{array}$ & $\begin{array}{l}.09^{*} \\
(.04)\end{array}$ & - & $\begin{array}{l}.12^{* *} \\
(.03)\end{array}$ & $\begin{array}{l}.10^{* *} \\
(.03)\end{array}$ \\
\hline $\begin{array}{l}\text { Father's } \\
\text { Duncan SEI }\end{array}$ & - & $\begin{array}{r}-.002 \\
(.006)\end{array}$ & $\begin{array}{r}-.004 \\
(.005)\end{array}$ & & $\begin{array}{l}.024^{* *} \\
(.006)\end{array}$ & $\begin{array}{l}.016^{* *} \\
(.006)\end{array}$ \\
\hline $\begin{array}{l}\text { Self- } \\
\text { employed }\end{array}$ & - & $\begin{array}{l}.49^{*} \\
(.23)\end{array}$ & $\begin{array}{l}.30 \\
(.23)\end{array}$ & - & $\begin{array}{l}.70^{* *} \\
(.24)\end{array}$ & $\begin{array}{l}.62^{* *} \\
(.23)\end{array}$ \\
\hline $\begin{array}{l}\text { Mother's } \\
\text { education }\end{array}$ & - & $\begin{array}{l}.21^{* *} \\
(.04)\end{array}$ & $\begin{array}{l}.17^{* *} \\
(.04)\end{array}$ & - & $\begin{array}{l}.08^{*} \\
(.04)\end{array}$ & $\begin{array}{l}.05 \\
(.04)\end{array}$ \\
\hline $\begin{array}{l}\text { Number of } \\
\text { siblings }\end{array}$ & - & $\begin{array}{c}-.18^{* *} \\
(.05)\end{array}$ & $\begin{array}{c}-.19^{* *} \\
(.05)\end{array}$ & - & $\begin{array}{c}-.14^{* *} \\
(.04)\end{array}$ & $\begin{array}{c}-.14^{* *} \\
(.04)\end{array}$ \\
\hline $\begin{array}{l}\text { Whether } \\
\text { Catholic }\end{array}$ & - & $\begin{array}{l}.24 \\
(.21)\end{array}$ & $\begin{array}{l}.11 \\
(.20)\end{array}$ & - & $\begin{array}{l}.28 \\
(.21)\end{array}$ & $\begin{array}{l}.30 \\
(.20)\end{array}$ \\
\hline $\begin{array}{c}\text { Whether } \\
\text { South }\end{array}$ & - & $\begin{array}{l}-.28 \\
(.25)\end{array}$ & $\begin{array}{l}-.31 \\
(.24)\end{array}$ & - & $\begin{array}{l}-.26 \\
(.22)\end{array}$ & $\begin{array}{l}-.25 \\
(.22)\end{array}$ \\
\hline $\begin{array}{l}\text { City } \\
\text { size (in } \\
\text { thousands) }\end{array}$ & - & $\begin{array}{c}.0001 \\
(.0005)\end{array}$ & $\begin{array}{r}-.0002 \\
(.0005)\end{array}$ & - & $\begin{array}{c}.0000 \\
(.0005)\end{array}$ & $\begin{array}{c}-.0003 \\
(.0005)\end{array}$ \\
\hline $\begin{array}{l}\text { Whether } \\
\text { black }\end{array}$ & - & $\begin{array}{l}.78^{*} \\
(.38)\end{array}$ & $\begin{array}{l}.95^{*} \\
(.37)\end{array}$ & - & $\begin{array}{l}.78^{*} \\
(.31)\end{array}$ & $\begin{array}{l}.98^{* *} \\
(.31)\end{array}$ \\
\hline Constant & $\begin{array}{c}10.99^{* *} \\
(.21)\end{array}$ & $\begin{array}{l}9.53^{* *} \\
(.46)\end{array}$ & $\begin{array}{l}9.65^{* *} \\
(.45)\end{array}$ & $\begin{array}{c}11.09^{* *} \\
(.20)\end{array}$ & $\begin{array}{c}10.19^{* *} \\
(.44)\end{array}$ & $\begin{array}{c}10.15^{* *} \\
(.43)\end{array}$ \\
\hline$R^{2}$ (adjusted) & .22 & .29 & .33 & .19 & .25 & .28 \\
\hline $\begin{array}{l}\text { Number of } \\
\text { observations }\end{array}$ & 398 & 398 & 398 & 456 & 456 & 456 \\
\hline
\end{tabular}

${ }^{a}$ Standard errors are given in parentheses. Coefficient tests are two tailed.

${ }^{*} p<.05$.

${ }^{* *} p<.01$.

with direct positive effects on the human capital acquired by children. The source of income is much less important than the amount.

Noneconomic theories view parental family income as important not so much for what it can buy, but for what it represents. They are concerned with how children are affected by growing up in a family with income from different sources. The success of children is affected crucially by their attitudes, aspirations, and social integration, and the development of these characteristics, in turn, is affected by different sources of family income. The source of parental income may therefore be a decisive factor in children's attainments as adults. Different theories emphasize different 
TABLE 2

Effects of Family Income and Various Background Measures on the In Wage Rate of Children $^{a}$

\begin{tabular}{|c|c|c|c|c|c|c|}
\hline \multirow[b]{2}{*}{$\begin{array}{l}\text { Total parental family } \\
\text { income in thousands }\end{array}$} & \multicolumn{3}{|c|}{ Sons } & \multicolumn{3}{|c|}{ Daughters } \\
\hline & $\begin{array}{l}.008^{* * *} \\
(.002)\end{array}$ & - & $\begin{array}{l}.006^{* * *} \\
(.002)\end{array}$ & $\begin{array}{l}.008^{* * *} \\
(.002)\end{array}$ & - & $\begin{array}{l}.004^{*} \\
(.002)\end{array}$ \\
\hline $\begin{array}{l}\text { Father's } \\
\text { education }\end{array}$ & - & $\begin{array}{r}-.004 \\
(.009)\end{array}$ & $\begin{array}{r}-.012 \\
(.010)\end{array}$ & - & $\begin{array}{l}-.029^{* * *} \\
(.009)\end{array}$ & $\begin{array}{l}-.031^{* * *} \\
(.009)\end{array}$ \\
\hline $\begin{array}{l}\text { Father's } \\
\text { Duncan SEI }\end{array}$ & - & $\begin{array}{r}-.001 \\
(.001)\end{array}$ & $\begin{array}{l}-.001 \\
(.001)\end{array}$ & - & $\begin{array}{l}.005^{* * *} \\
(.002)\end{array}$ & $\begin{array}{l}.004^{* *} \\
(.002)\end{array}$ \\
\hline Self-employed & - & $\begin{array}{l}-.170^{* * * *} \\
(.064)\end{array}$ & $\begin{array}{l}-.202^{* * *} \\
(.064)\end{array}$ & - & $\begin{array}{c}-.131^{*} \\
(.068)\end{array}$ & $\begin{array}{c}-.143^{* *} \\
(.068)\end{array}$ \\
\hline $\begin{array}{l}\text { Mother's } \\
\text { education }\end{array}$ & - & $\begin{array}{l}.035^{* * *} \\
(.012)\end{array}$ & $\begin{array}{l}.029^{* *} \\
(.012)\end{array}$ & - & $\begin{array}{l}.041^{* * *} \\
(.012)\end{array}$ & $\begin{array}{l}.036^{* * *} \\
(.012)\end{array}$ \\
\hline $\begin{array}{l}\text { Number of } \\
\text { siblings }\end{array}$ & - & $\begin{array}{l}.000 \\
(.013)\end{array}$ & $\begin{array}{l}.000 \\
(.013)\end{array}$ & - & $\begin{array}{r}-.016 \\
(.014)\end{array}$ & $\begin{array}{r}-.016 \\
(.014)\end{array}$ \\
\hline $\begin{array}{l}\text { Whether } \\
\text { Catholic }\end{array}$ & - & $\begin{array}{r}-.020 \\
(.058)\end{array}$ & $\begin{array}{r}-.031 \\
(.057)\end{array}$ & - & $\begin{array}{l}.040 \\
(.062)\end{array}$ & $\begin{array}{c}.034 \\
(.062)\end{array}$ \\
\hline $\begin{array}{l}\text { Whether } \\
\text { South }\end{array}$ & - & $\begin{array}{c}-.183^{* * *} \\
(.069)\end{array}$ & $\begin{array}{l}-.184^{* * *} \\
(.068)\end{array}$ & - & $\begin{array}{l}-.030 \\
(.066)\end{array}$ & $\begin{array}{r}-.043 \\
(.066)\end{array}$ \\
\hline $\begin{array}{l}\text { City size } \\
\text { (in thousands) }\end{array}$ & - & $\begin{array}{l}.0004^{* * *} \\
(.0001)\end{array}$ & $\begin{array}{l}.0003^{* *} \\
(.0001)\end{array}$ & - & $\begin{array}{l}.0005^{* * *} \\
(.0001)\end{array}$ & $\begin{array}{l}.0004^{* * *} \\
(.0001)\end{array}$ \\
\hline $\begin{array}{c}\text { Whether } \\
\text { black }\end{array}$ & - & $\begin{array}{c}-.210^{* *} \\
(.104)\end{array}$ & $\begin{array}{c}-.175^{*} \\
(.104)\end{array}$ & - & $\begin{array}{c}-.080 \\
(.098)\end{array}$ & $\begin{array}{r}-.052 \\
(.099)\end{array}$ \\
\hline $\begin{array}{l}\text { County } \\
\text { unemployment } \\
\text { (in \%) }\end{array}$ & $\begin{array}{r}-.003 \\
(.011)\end{array}$ & $\begin{array}{c}-.005 \\
(.011)\end{array}$ & $\begin{array}{c}-.006 \\
(.011)\end{array}$ & $\begin{array}{c}-.009 \\
(.012)\end{array}$ & $\begin{array}{c}-.012 \\
(.012)\end{array}$ & $\begin{array}{r}-.014 \\
(.012)\end{array}$ \\
\hline Constant & $\begin{array}{l}1.85^{* * * *} \\
(.10)\end{array}$ & $\begin{array}{l}1.79^{* * *} \\
(.16)\end{array}$ & $\begin{array}{l}1.80^{* * *} \\
(.16)\end{array}$ & $\begin{array}{l}1.54^{* * * *} \\
(.11)\end{array}$ & $\begin{array}{l}1.47^{* * *} \\
(.17)\end{array}$ & $\begin{array}{l}1.48^{* * *} \\
(.17)\end{array}$ \\
\hline$R^{2}$ (adjusted) & .07 & .13 & .16 & .06 & .14 & .15 \\
\hline $\begin{array}{l}\text { Number of } \\
\text { observations }\end{array}$ & 328 & 328 & 328 & 317 & 317 & 317 \\
\hline
\end{tabular}

${ }^{a}$ Standard errors are given in parentheses. Coefficient tests are two tailed.

${ }^{*} p<.10$.

${ }^{* *} p<.05$.

${ }^{* * *} p<.01$.

sources of income, underscoring variously the importance of role models, the working mother, or the welfare culture.

Apart from these theories, there are some statistical reasons to expect differential effects by type of income. Certain kinds of income-in particular income from asset or welfare sources-may signal otherwise unmeasured characteristics in parents who are exceptionally productive or uproductive. We also explore the implications of this possibility. 


\section{Economic Theory}

Becker's intergenerational model is concerned with how the allocation of resources within the family, broadly defined, affects the development of the skills, or human capital, of children. ${ }^{6}$ It assumes that parents are concerned with the welfare of their children and are willing to spend money to improve their likely future standard of living. ${ }^{7}$ Parents must allocate their given family income between current consumption, on the one hand, and schooling and other "investments" in the skills of their children, on the other. In determining how much to invest in children, parents are presumed to take into consideration, when possible, all of the different factors that will contribute to the children's future standard of living. These include, in addition to the skills of children, childhood "endowments" and market luck. Childhood endowments consist of incomeearning qualities that are determined by the reputation, connections, or genes of their families, the "learning, skills, goals . . . acquired through belonging to a particular family culture" (Becker and Tomes, 1979:1158), and the influence of the culture as a whole. Parents are assumed to have no control over market luck, which reflects random events such as macroeconomic fluctuations in the labor market, and its value is not apparent until the children have become adults. The model produces a parental "demand" equation for the future income of children that is a positive and additive function of parental family income, childhood endowments, and market luck, with the first two known to parents and the latter not.

The role of various components of parental income in the Becker model is somewhat unclear. Economic models usually do not distinguish between kinds of income according to their source, since dollars are fungible. The basic focus of Becker's intergenerational model, though, is on the

${ }^{6}$ For applications of the Becker model to the intergenerational framework, see Becker (1981), Tomes (1981), Becker and Tomes (1979), and Ishikawa (1975). A subsequent version of the model, developed in Becker and Tomes (1986), introduces the assumption of perfect capital markets, allowing parents at all income levels to finance human capital investments in children without reducing parental consumption by borrowing on the expected future earnings of their children. A major implication is that parental earnings would not affect the level of expenditures on children, thus eliminating any direct effect of parental income on the earnings and human capital of children. Indirect effects of parental income would, however, operate via endowments (e.g., family "contacts") whether or not perfect capital markets existed. Since the assumption of perfect capital markets is not very realistic, the Becker model we describe includes positive direct effects of parental income. In doing so, it places less emphasis on indirect effects via endowments than the Becker and Tomes (1986) paper does.

${ }^{7}$ The model yields similar implications whether the parents are assumed to care only about child quality, as measured by the wealth of children, or are assumed to be altruists, with their preferences reflecting concern about the well-being of all family members. See Becker and Tomes (1979:1156 and Appendix A) for further details regarding this distinction. Underlying the theory, however, is an assumption of a single-family utility function, the violation of which could produce effects that vary by income source. 
human and nonhuman wealth of both generations, and not on other income sources, such as transfers. However, Becker's treatment of government sector effects can be extended to imply that the effect of transfer subsidies on the child's attainment is equal to that of parental earnings. ${ }^{8}$ This result plus the presumed fungibility of income leads to the key testable idea from Becker's intergenerational model-an expectation of similar effects of all parental income sources on the human capital acquired by children. ${ }^{9}$ Proper testing of this hypothesis requires enough controls for the effects of childhood endowments so that there are no substantial correlations between observed income components and unobserved endowments.

\section{Role Model Hypothesis}

Socialization theory views the significance of fathers' and mothers' labor income on children's attainments as going beyond that of income as an economic resource. In this view, parental income affects the cognitive and emotional development of children in that it reflects the examples, or role models, parents provide for their children. These role models can be of two distinct types (Woelfel and Haller, 1971:76). First, a parent can offer an example for the child as a person (model for self):

insofar as ego [the child] considers others [the parents] to be a member of the same category as himself, the other's actions help define that category and consequently his conception of himself. (Woelfel and Haller, 1971:76).

Since the identity of the child is most strongly linked with that of the parent of the same sex, the effect of parental behavior on children is thought to be strongest for father-son and mother-daughter pairs (Santrock, 1972:457). Parents can also serve as role models by dcfining through their own actions objects or concepts, such as "success." In this way parents provide models for objects.

${ }^{8}$ This result can be dervied from Becker's model if government transfers are treated as a negative income tax with a fixed floor on income. In this case, the coefficient on the subsidy is identical to the coefficient on other components of parental wealth.

${ }^{9}$ An alternative to the Becker intergenerational model is the transaction cost approach, in which family members operate as separate bargaining units and engage in transactions with one another (Ben-Porath, 1980; Pullack, 1985). Mutual self-interest rather than concern for other family members motivates the actors. This theory allows for the possibility of the family serving as an alternative capital market to finance loans, including educational and other human capital training loans. Since bargaining between distinct individuals is the crucial decision-making tool, the outcome is less determinant. To the extent that the pool of parental wealth determines the potential for financial loans, however, one would expect it to have a positive effect on the attainments of children. Only this very weak test of the transactions cost approach would be possible with our data. 
To the extent that parental labor income indicates labor market success or failure, the parent's labor income reflects the quality of the labor market role model provided by the parent, as a "model for self" and as a "model for objects," and can be expected to have a positive effect on the child's labor market qualifications and attainments. A father's labor income positively affects his child's labor income, especially if the child is a son; a mother's labor income, likewise, positively affects her child's labor income, especially if the child is a daughter.

The amount of completed schooling is also likely to be affected by the process of role modeling. ${ }^{10}$ By defining success at a higher level than less successful parents, successful parents-whether their success is due to high educational attainment or high labor market earnings-stimulate the child's motivation for achievement. This, in turn, contributes to success in school, including higher educational attainment.

One issue not directly addressed by the role model literature, but important to our tests of the theory, involves the fact that role model effects may vary with household structure." Role model effects are generally thought of as being exerted by parents residing in the child's household. However, even though not living in the household, an absent parent who is successful could also be a role model for his children. In addition, an adult present in the child's household might have a differing role model influence depending on whether he or she is the child's biological parent or stepparent. We address only the first two aspects of these distinctions, since data limitations preclude differentiation of parents into biological and stepparent categories.

\section{Working Mother Hypothesis}

Sometimes referred to as the "mother absent" hypothesis in the literature about single parents, the working mother hypothesis depicts employment by the mother outside the home as a source of developmental problems in children, rather than as a means of promoting attributes needed for adult roles. A mother who is employed is thought to offer less supervision, training, and socialization for her children, which in turn results in poorer school performance and behavioral problems in school, including less consistent school attendance and more attention-getting behavior. ${ }^{12}$

This hypothesis conflicts with the role model theory in that it predicts that the mother's labor market income will have a negative, rather than a positive, effect on the child's educational attainment, unlike other forms

${ }^{10}$ McLanahan (1985) makes this argument in the context of the effects of the absence of a father.

${ }^{11}$ We are grateful to Arland Thorton for making these distinctions clear.

12 These arguments are spelled out in McLanahan (1985), Hetherington et al. (1983), Shinn (1978), and Ross and Sawhill (1975). 
of income. To the extent that educational attainment would also affect one's wage level, the child's wage rate might also be expected to be affected negatively by his mother's outside employment. This theory makes no distinction between sons and daughters in terms of expected effects.

\section{Welfare Culture}

The welfare culture theory, sometimes termed the "class-related intergenerational pathology hypothesis," views welfare itself as the means by which detrimental attributes develop in children whose parents depend on it:

\footnotetext{
Welfare saps the capacity of recipients for independent action, damages selfesteem, and reinforces feclings of personal inadequacy, failure and worthlessness. Since traits of autonomy, independence, ambition, and coping are supposedly not reinforced during a childhood on welfare, the welfare child is destined to become a welfare recipient. ${ }^{13}$
}

The welfare child is also likely to be doomed to lower educational attainment and lower wages. The implication of this hypothesis is that welfare income adversely affects the child's education and wage rate. Although not mentioned explicitly in this literature, it seems reasonable to expect the strongest welfare culture effects for children growing up in families where welfare is received for extended periods of time and where welfare dominates the family income package.

\section{Income as Signals}

Income may also show spurious links to the attainment of children if unmeasured parental characteristics are correlated with both parental income and the productive characteristics of the child. Asset and welfare income arc cspecially likely to embody such effects. Parents with uninherited asset income may be more farsighted, better able to plan or have other productive characteristics relative to those without such income. The opposite may hold for welfare: unmeasured characteristics of parents with welfare income are very likely to be counterproductive. Thus especially the first and possibly each additional dollar of asset income might be expected to have a more positive effect on childhood attainments than that of other types of parental income. Similar conclusions might be drawn about welfare income, except that the effect of welfare income might be expected to be more negative than that of other forms of income.

\footnotetext{
${ }^{13}$ Macaulay (1977:77) describes the theory in this manner and subsequently evaluates evidence concerning it.
} 


\section{RESULTS FROM THE BASIC MODEL AND ITS EXTENSIONS}

Many of the hypotheses about the effects of the components of family income have implications for the coefficients of a model that relates the attainments of children to those components. As outlined above, our basic model distinguishes among five income components-father's labor, mother's labor, asset, welfare, and all other income-as well as allowing for distinction between the effects of the first dollar of a given income type and those of subsequent dollars. ${ }^{14}$ The background measures included in Tables 1 and 2 are also included in our basic model, so the income effects are estimated net of any differences in parental schooling, family size, location, or any of the other background measures.

The estimated coefficients of the income components in the basic model are presented in Table 3. For the sake of convenience, the coefficients of the first dollar of each income type are scaled in whole dollars while those on the added dollars are scaled in thousands of dollars. Thus, the first dollar of a father's labor income is associated with about half (.527) a year less education for his son, while every additional thousand dollars of the father's labor income is associated with a .034 year increase in the son's schooling. The first of these coefficients, which shows the effect of having a father present and earning one dollar as opposed to having no father present during the 3-year period, is not statistically significant at conventional levels, while the second one, which shows the incremental effect of additional thousands of dollars of fathers' income, is. ${ }^{15}$ Taken

14 This two-segment spline is equivalent to adding dummy variables indicating whether or not each income type is positive. A more flexible functional form for the income components would be a set of dummy variables or spline segments. Our choice of the two-segment spline was based on a desire for simplicity and on experimentation that showed that the two segments represented the data reasonably well; using additional pieces of the spline function (e.g., allowing different slopes for the income segments above and below the mean) and using more detailed disaggregations of income did not produce substantially different results from those found with the simpler specification. The appendix shows the weighted fraction of the sample and unweighted case counts associated with zero amounts of the various income components. For each income component, there was a sufficient number of zero (and nonzero) cases to permit reliable estimation.

is Also of interest is whether the cuefficient on the first segment of the spline function is significantly different from the coefficient on the second segment. Given the magnitude, variances, and covariances of the coefficients involved, a test for different slopes produced patterns of effects that were identical to the tests to determine whether the coefficients on the first segments were significantly different from zero. Of the 209 total cases with zero amounts of father's labor income, 34 had fathers present in at least one of the 3 years. Thus it is not strictly correct that the coefficient on the first dollar represents the attainment difference between children in father-absent households and the projection of the income-attainment regression line estimated for additional dollars of fathers' income back to a single dollar. Similar interpretations apply to the coefficients on the first dollars of other income components. Our concern that these somewhat hypothetical projections might misrepresent the effect of the first dollar lead us to estimate a number of alternative specifications for the additional dollar segments. None of them changed the first-dollar coefficients appreciably. 
TABLE 3

Effects of First and Added Dollars of Income from Various Sources on Education and In Wage Rates of Children ${ }^{a}$

\begin{tabular}{|c|c|c|c|c|}
\hline & \multicolumn{4}{|c|}{ Dependent variable and subgroup } \\
\hline & \multicolumn{2}{|c|}{$\begin{array}{l}\text { Completed education } \\
\text { of child }\end{array}$} & \multicolumn{2}{|c|}{$\begin{array}{l}\text { In wage rate } \\
\text { of child }\end{array}$} \\
\hline & Sons & Daughters & Sons & Daughters \\
\hline \multicolumn{5}{|l|}{$\begin{array}{l}\text { Effect of first } \\
\text { dollar of: }\end{array}$} \\
\hline $\begin{array}{l}\text { Father's labor } \\
\text { income }\end{array}$ & $\begin{array}{l}-.527 \\
(.334)\end{array}$ & $\begin{array}{l}-.916^{* * *} \\
(.343)\end{array}$ & $\begin{array}{l}-.010 \\
(.090)\end{array}$ & $\begin{array}{l}.008 \\
(.112)\end{array}$ \\
\hline $\begin{array}{l}\text { Mother's labor } \\
\text { income }\end{array}$ & $\begin{array}{l}-.188 \\
(.212)\end{array}$ & $\begin{array}{r}-.358^{*} \\
(.203)\end{array}$ & $\begin{aligned}-.102^{*} \\
(.058)\end{aligned}$ & $\begin{aligned}-.088 \\
(.064)\end{aligned}$ \\
\hline Asset income & $\begin{array}{l}.626^{* * *} \\
(.208)\end{array}$ & $\begin{array}{l}.750^{* * *} \\
(.208)\end{array}$ & $\begin{array}{l}-.045 \\
(.056)\end{array}$ & $\begin{array}{l}.056 \\
(.065)\end{array}$ \\
\hline Welfare income & $\begin{array}{l}.127 \\
(.328)\end{array}$ & $\begin{array}{l}-.940^{* * *} \\
(.284)\end{array}$ & $\begin{array}{r}-.080 \\
(.091)\end{array}$ & $\begin{array}{l}.123 \\
(.099)\end{array}$ \\
\hline All other income & $\begin{array}{c}-.443 \\
(.327)\end{array}$ & $\begin{array}{r}-.179 \\
(.255)\end{array}$ & $\begin{array}{c}.111 \\
(.092)\end{array}$ & $\begin{array}{r}-.013 \\
(.082)\end{array}$ \\
\hline \multicolumn{5}{|c|}{$\begin{array}{l}\text { Effects of additional } \\
\text { (thousand) dollars of: }\end{array}$} \\
\hline $\begin{array}{l}\text { Father's labor } \\
\text { income }\end{array}$ & $\begin{array}{l}.034^{* * *} \\
(.009)\end{array}$ & $\begin{array}{l}.024^{* * *} \\
(.008)\end{array}$ & $\begin{array}{l}.008^{* * *} \\
(.002)\end{array}$ & $\begin{array}{l}.005^{*} \\
(.003)\end{array}$ \\
\hline $\begin{array}{l}\text { Mother's labor } \\
\text { income }\end{array}$ & $\begin{array}{l}.024 \\
(.018)\end{array}$ & $\begin{array}{l}.038^{* *} \\
(.019)\end{array}$ & $\begin{array}{c}-.004 \\
(.005)\end{array}$ & $\begin{array}{r}.001 \\
.006)\end{array}$ \\
\hline Asset income & $\begin{array}{r}-.018 \\
(.026)\end{array}$ & $\begin{array}{l}.084^{* * *} \\
(.026)\end{array}$ & $\begin{array}{l}.003 \\
(.007)\end{array}$ & $\begin{array}{c}.002 \\
(.008)\end{array}$ \\
\hline Welfare income & $\begin{array}{c}-.013 \\
(.048)\end{array}$ & $\begin{array}{l}.069 \\
(.049)\end{array}$ & $\begin{array}{l}.001 \\
(.013)\end{array}$ & $\begin{array}{r}-.018 \\
(.019)\end{array}$ \\
\hline All other income & $\begin{array}{r}.024 \\
(.017)\end{array}$ & $\begin{array}{c}-.003 \\
(.018)\end{array}$ & $\begin{array}{l}.006 \\
(.004)\end{array}$ & $\begin{array}{l}.011^{*} \\
(.007)\end{array}$ \\
\hline Constant & $\begin{array}{l}10.44^{* * *} \\
(.65)\end{array}$ & $\begin{array}{l}11.49 * * * \\
(.58)\end{array}$ & $\begin{array}{l}1.83^{* * * *} \\
(.20)\end{array}$ & $\begin{array}{l}1.51^{* * *} \\
(.21)\end{array}$ \\
\hline $\begin{array}{l}R^{2} \text { (adjusted) } \\
\text { Number of } \\
\text { observations }\end{array}$ & .34 & .33 & .20 & .14 \\
\hline
\end{tabular}

${ }^{a}$ Other predictor variables included in the analysis are those listed in Table 1 for the education regression and Table 2 for the wage regression. Standard errors are given in parentheses. Coefficient tests are two tailed.

$\begin{aligned}{ }^{*} p & <.10 . \\ { }^{* *} p & <.05 \\ { }^{* * *} p & <.01 .\end{aligned}$

literally, these coefficients suggest that only at father income levels greater than $15.5(=.527 / .034)$ thousand dollars are sons better off in terms of educational attainment than if no father were present in the household. We investigate the effects of the father's absence in greater detail below. 
Results for the background measures included in these regressions did not differ significantly from those shown in columns 3 and 6 of Tables 1 and 2, and are therefore omitted from Table 3.

Most of the hypotheses outlined above require that various constraints be imposed on the coefficients of the model. Nevertheless, it is useful to direct our attention to the unconstrained coefficients contained in Table 3, about which a few summary comments are in order. First, a comparison of the explained variance, adjusted for degrees of freedom, of the regressions in Table 3 with comparable regressions in the third and sixth columns of Tables 1 and 2 shows that decomposing total income into its components results in a substantial increase in explained variance in two of the four cases and a decrease in only one case. Second, fathers' labor income is clearly the most significant component in all four of the regressions, although the point estimates of other coefficients are occasionally higher and the size of the standard errors on the coefficients argues against drawing hasty conclusions, without additional testing, about the relative importance of the various income sources.

We organize our discussion by treating the various hypotheses in the same order in which they appeared in Section 3. A summary of the tests performed and their results is presented in Table 4.

\section{Becker's Intergenerational Model}

Becker's intergenerational model of attainment views parents as concerned for the welfare of their children and willing to sacrifice their own consumption for the sake of investing in the human capital "wealth" of their children. This theory is usually formulated in terms of the stock of wealth of the parent and child rather than as income flows, but the 3-year average income amounts measured in our data can be viewed as roughly proportional to the human and nonhuman wealth of the parents. The more direct link between asset income and the stock of assets themselves leads us to distinguish between income from assets and from other sources.

The regressions reported in the third and sixth columns of Tables 1 and 2 have a rough correspondence to Becker's basic demand equation, since total 3-year parental income constitutes a measure of parental permanent income; the other background measures can be thought of as controls for childhood endowments; market luck, if random, can be ignored without biasing the coefficients of the included variables; and the value of the stock of human capital of the children is captured by the two dependent variables, completed schooling and $\ln$ wage rate. ${ }^{16}$

16 These outcomes are the most reliable indicators of the value of the child's capital we have and are less dependent on family structure decisions than are outcomes such as total family income or family income/needs. 
HILL AND DUNCAN

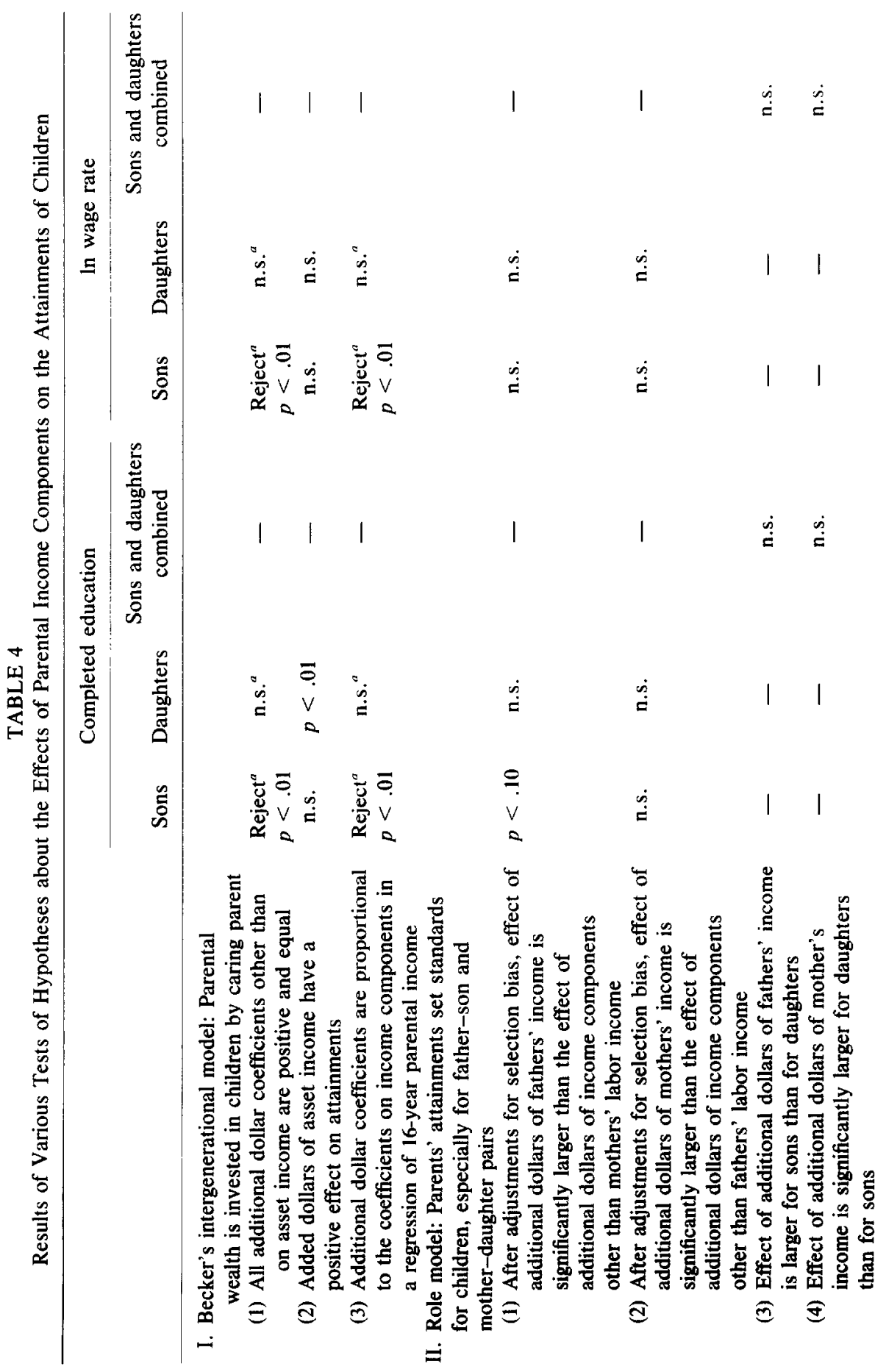




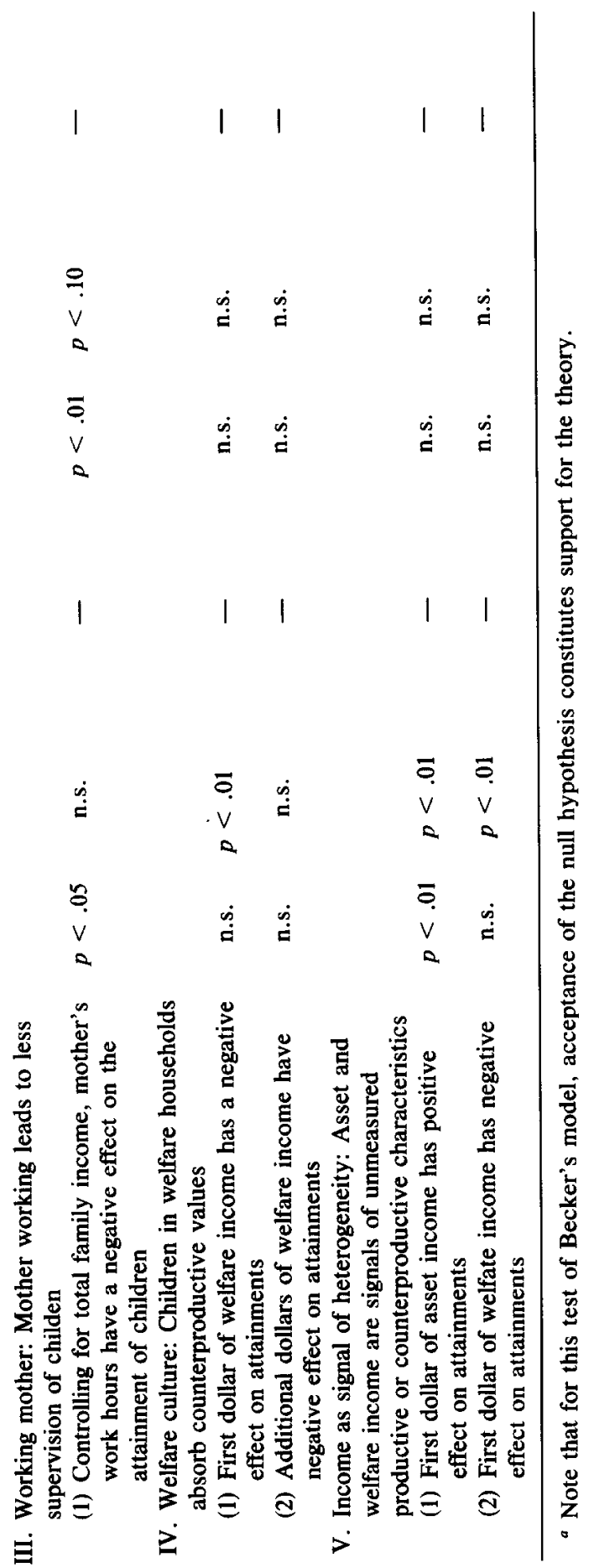


To the extent that crucial endowment factors (e.g., genes) are omitted and correlate with both parental income and children's attainment, coefficient estimates of parental income will be biased. Biases will also be present if the nonrandomness of market luck (e.g., recessions systematically harm certain workers) is correlated with parental income and the attainment of the children.

The idea in Becker's intergenerational model that parental family income should be treated at face value as a pooled resource available to the parents for possible investments in children suggests that the effects of additional dollars of income from labor market and from welfare sources should be similar. This test takes the form of a null hypothesis: the effects of additional dollars from all sources other than assets on the attainments of children should be positive and insignificantly different from one another.

The dispersion of point estimates shown in Table 3 for the coefficients of the added dollars from various sources, in particular the larger coefficient on fathers' income, leads to a rejection of the null hypothesis of no difference for both dependent variables for men. Coefficients for women are much more similar, and for them the null hypothesis could not be rejected at conventional levels of statistical significance for either dependent variable. ${ }^{17}$ The data, then, are consistent with the proposition that families invest their income in daughters but not in sons without regard to its source.

The relatively direct link between income from assets and the amount of financial wealth led us to treat income from that source differently. Here the hypothesis is a simple one: that additional dollars of asset income have positive effects on the attainments of children. A one-tailed test on the added dollars of asset income included in Table 3 shows that in only one case, the completed education of daughters, is there a significant effect, thus providing only very limited support for that aspect of the investment view. ${ }^{18}$

${ }^{17}$ The tests were performed in LIMDEP using the Wald statistic that compares the variance of the unconstrained and constrained estimates of the coefficient of the income components. It is possible that the hypothesis of equal effects was rejected for sons because of some correlation between unmeasured components of child endowments and the income component-in this case father's labor income-whose coefficient was different from the others. To be consistent with the full set of results, the endowment component would have to produce the offending correlation for sons but not daughters and for both the schooling and wage rate outcomes of sons. None of the most commonly discussed endowment characteristics (e.g., genes, labor market connections, advantaged environments) can be argued to produce such a pattern readily.

${ }^{18}$ One reason for the weak link between asset income and children's attainment, suggested to us by a referee, is that the presence of asset income could signal past lack of investment in children. 
One potential problem with these tests is that the theory calls for a measure of parental wealth throughout childhood, and our data provide information on components of income only during the period when the child is 14 to 16 years of age. An extreme economic perspective might hold that shortrun parental income is likely to be a much worse indicator of parental wealth than many of the background measures, most notably father's education and occupation and mother's education. To investigate the nature of the association between income during the 3 childhood years in our analysis and a much better indicator of parental wealthtotal income during childhood as a whole-we selected an entirely different cohort of children from the PSID, consisting of individuals who were age 1-3 in the first year of the study (1968) and for whom 16 years of subsequent family income information were available. We used this income information to compute total family income, inflated to 1982 price levels and averaged over the entire 16-year period. We then computed the same five income components (father's labor, mother's labor, asset, welfare, and other sources) as in our attainment regressions, averaged over the period when this second sample of children were between the ages of 14 and 16. A regression of the 16-year total average income on the components averaged over the 3 teen years produced the following coefficients and, in parentheses, standard errors:

Average 16-year family income $=$ $\$ 10,048+.6703$-year average father's labor income

+.500 3-year average mother's labor income

+.362 3-year average asset income (.024)

+.1113 -year average welfare income

+.567 3-year average other income.

$$
R^{2}=.844 \text {. }
$$

Not surprisingly, father's labor income is most predictive of total childhood income, with a coefficent of .67 , but the coefficients on mother's labor income and the residual income category are both larger than .50 . Quite surprisingly, welfare income is an insignificant predictor of total childhood income, perhaps reflecting the temporary nature of much welfare receipt (Bane and Ellwood, 1983). The very high explained variance in this regression assures us that the 3-year measures used in our analysis capture much of the variance in parental wealth.

We used the coefficients from this auxiliary regression to provide a different set of constraints on the coefficients in our basic attainment 
model. Specifically, we tested whether the coefficients of the added dollar components were proportional to the coefficients in the 16-year auxiliary regression. The results of that test were identical to the results of our original test of equality of all but the asset income coefficients: the constrained coefficients were significantly different from the unconstrained coefficients for both attainment regressions for sons but insignificantly different for both attainment regressions for daughters. ${ }^{19}$

\section{Role Model}

Socialization theory contends that parents' actions set standards that children will attempt to follow as adults, and that this is particularly true with regard to parent-child pairs of the same sex. Parents' labor income not only serves as a standard for children's labor market success but also offers a general standard for achievable levels of success that affects achievement motivation and, through this path, the child's success in endeavors such as school performance. This implies that parents' income affects areas over and above the economic sphere.

While the total labor income of the child might at first glance seem to be the best outcome measure for testing the parent-to-child labor market success relationship, labor supply constraints during the early adult years may make the earnings per hour worked a better indicator of the early labor market success of the child. We report results for children's wage rates but found virtually identical patterns when total labor income was used instead. Success in school is measured by completed years of schooling.

The role model hypothesis is most applicable when a parent is present in the household and serving as an active role model, with increments in the success level of the parent expected to affect positively the attainments of the child. Testing this hypothesis is complicated by the possibility that the parent is either absent from the child's home (as in the case of divorced fathers) or not participating in the labor market (as in the case of nonemployed mothers). These situations represent discrete rather than incremental differences in role model influences. Consequently, tests of the marginal effects of fathers' or mothers' income when they are serving as present-and-active role models must control for the likelihood that these discrete differences will occur.

${ }^{19}$ Since the coefficients from the 16-year sample regression are themselves subject to sampling error, it is not quite proper to treat them as fixed. We did not attempt the more complicated test. Another use of the auxiliary information from this separate sample is to assess the extent to which the 3-year total family income measure used in the regressions reported in Tables 1 and 2 might understate the effect of the more desirable measure of total family income available during the entire period of childhood. The correlation between the 3-year measure and 16-year measure was quite high-.907-indicating little likely bias from measurement error in the 3-year measure. 
The spline function controls for the lack of a role model by differentiating between the first dollar and additional dollars of parental income. Estimates from it are presented in Table 3. Coefficients on subsequent income beyond the first dollar of the labor income of father and mother reflect role model effects for children with active role models. Coefficients on fathers' labor income are positive and significantly different from zero in all cases. Coefficients on mothers' labor income are generally insignificant, especially for the In wage.

A more precise test of the present-and-active father role model hypothesis examines whether the coefficient on subsequent dollars of father's labor income is significantly higher than the coefficient on subsequent dollars of income from sources other than a parent's income. Presumably the coefficient on these other income sources indicates economic effects, and the proper role model test is one for effects over and above these economic effects. The results from these supplemental regressions required for this approach are shown in the top panel of Table 5. In only one case-with regard to the educational attainment of sons-is the coefficient on father's income significantly higher than the coefficient on nonlabor income sources. ${ }^{20}$ Thus there is at best weak support for the presentand-active father role model hypothesis in these data.

Also of interest is the effect of the absence of the father as role model. Conventional tests to determine whether absent fathers provide a different and negative role model for sons require contrasting the attainment of children reared in father-present and father-absent households. The spline function (Table 3) provides one type of contrast, with the effect of the first dollar of father's income distinguishing these two types of households. But this effect contrasts the attainments of children raised in fatherabsent households only with the attainments of children from households in which fathers are present but have extremely low earnings. A more relevant comparison is between father-absent households and "otherwise similar" father-present households. A set of supplemental regressions were run on the education and ln wage rates of children from fatherpresent and father-absent households with and without controls for total family income, but always with controls for the parental background

${ }^{20}$ The role model tests for fathers' income were performed both with father's characteristics that could influence the quality of his role model (father's Duncan SEI and education) and without these characteristics. The omission of the education and SEI of the father increased the coefficient on fathers' income in most cases, but not enough to alter substantially the conclusions drawn from the regressions that included those two measures. With measures of father's education and SEI included in the regression of educational attainment for sons, the $t$ ratio of the difference in coefficients between father's income and income other than mother's income was 1.53 , which exceeds the 1.28 critical $10 \% t$ value for a one-tailed test. Without measures of father's education and SEI, the $t$ ratio was 1.67. The relative importance of father's income for the completed education of daughters also rose, but did not attain statistical significance at the .10 level. 


\section{TABLE 5}

Results from Supplementary Regressions on Effects of Parental Income Components and Mothers' Work Hours on Education and In Wage Rates of Children ${ }^{a}$

\begin{tabular}{|c|c|c|c|c|}
\hline & \multicolumn{4}{|c|}{ Dependent variable and subgroup } \\
\hline & \multicolumn{2}{|c|}{$\begin{array}{l}\text { Completed education } \\
\text { of child }\end{array}$} & \multicolumn{2}{|c|}{$\begin{array}{l}\text { In wage rate } \\
\text { of child }\end{array}$} \\
\hline & Sons & Daughters & Sons & Daughters \\
\hline \multicolumn{5}{|l|}{ Father-present role model } \\
\hline Fathers' labor income (in thousands) & $\begin{array}{l}.038^{* * *} \\
(.008)\end{array}$ & $\begin{array}{l}.034^{* * * *} \\
(.008)\end{array}$ & $\begin{array}{l}.008^{* * *} \\
(.002)\end{array}$ & $\begin{array}{l}.004^{*} \\
(.003)\end{array}$ \\
\hline $\begin{array}{l}\text { Other income (except mothers' labor } \\
\text { income, in thousands) }\end{array}$ & $\begin{array}{l}.015 \\
(.014)\end{array}$ & $\begin{array}{l}.024^{*} \\
(.015)\end{array}$ & $\begin{array}{l}.005 \\
(.004)\end{array}$ & $\begin{array}{l}.007 \\
(.005)\end{array}$ \\
\hline $\begin{array}{l}\text { Significance level of one-tailed test of } \\
\text { difference }\end{array}$ & $p<.10$ & n.s. & n.s. & n.s. \\
\hline \multicolumn{5}{|l|}{ Father-absent role model } \\
\hline Not adjusted for family income & $\begin{array}{l}.483^{* *} \\
(.248)\end{array}$ & $\begin{array}{c}.377 \\
(.244)\end{array}$ & $\begin{array}{l}.148^{* *} \\
(.065)\end{array}$ & $\begin{array}{l}.075 \\
(.071)\end{array}$ \\
\hline Adjusted for family income & $\begin{array}{l}.148 \\
(.254)\end{array}$ & $\begin{array}{l}.069 \\
(.252)\end{array}$ & $\begin{array}{l}.095 \\
(.068)\end{array}$ & $\begin{array}{l}.031 \\
(.076)\end{array}$ \\
\hline \multicolumn{5}{|l|}{ Mother role model ${ }^{b}$} \\
\hline Mothers' labor income (in thousands) & $\begin{array}{l}.014 \\
(.024)\end{array}$ & $\begin{array}{l}.011 \\
(.027)\end{array}$ & $\begin{array}{l}-.016 * * \\
(.006)\end{array}$ & $\begin{array}{l}-.001 \\
(.009)\end{array}$ \\
\hline $\begin{array}{l}\text { Other income (except fathers' labor } \\
\text { income, in thousands) }\end{array}$ & $\begin{array}{l}.054^{*} \\
(.028)\end{array}$ & $\begin{array}{l}.090^{* * *} \\
(.023)\end{array}$ & $\begin{array}{c}.009 \\
(.007)\end{array}$ & $\begin{array}{l}.014^{* *} \\
(.007)\end{array}$ \\
\hline$\lambda$ & $\begin{array}{c}.902 \\
(1.082)\end{array}$ & $\begin{array}{l}.696 \\
(.947)\end{array}$ & $\begin{array}{l}.059 \\
(.282)\end{array}$ & $\begin{array}{c}.458 \\
(.288)\end{array}$ \\
\hline $\begin{array}{l}\text { Significance level of one-tailed test of } \\
\text { difference }\end{array}$ & n.s & n.s. & n.s. & n.s. \\
\hline \multicolumn{5}{|l|}{ Working mother } \\
\hline Mothers' work hours (in thousands) & $\begin{array}{l}-.237^{* *} \\
(.115)\end{array}$ & $\begin{array}{l}-.123 \\
(.117)\end{array}$ & $\begin{array}{c}-.077^{* *} \\
(.031)\end{array}$ & $\begin{array}{l}-.046 \\
(.034)\end{array}$ \\
\hline $\begin{array}{l}\text { Total family income (from all sources, } \\
\text { in thousands) }\end{array}$ & $\begin{array}{l}.033^{* * *} \\
(.007)\end{array}$ & $\begin{array}{l}.032^{* * *} \\
(.007)\end{array}$ & $\begin{array}{l}.006 * * * \\
(.002)\end{array}$ & $\begin{array}{l}.005^{* *} \\
(.002)\end{array}$ \\
\hline
\end{tabular}

${ }^{a}$ All regressions include parental control variables listed in Tables 1 and 2 and all components of parental income. Standard errors are given in parentheses. Unless noted otherwise, significance tests on coefficients are two tailed.

${ }^{b}$ Coefficients are adjusted for selection bias, as explained in the text.

$* p<.10$.

${ }^{* *} p<.05$.

${ }^{* * *} p<.01$.

measures included in Tables 1 and 2. These analyses, shown in the second panel of Table 5, produce dramatic differences depending on whether or not we controlled for parental family income. When we did not control for income, sons but not daughters from father-absent households showed significantly less schooling and lower wage rates. Controls for parental 
income reduced coefficients for sons by between one-third and over twothirds and for daughters by even greater amounts; none of the incomeadjusted coefficients on the measure of father's absence for sons or daughters was significantly negative. Thus, absent-father effects are, for the most part, actually income effects. McLanahan (1985) also finds absent-father effects on education to be largely income effects, but her work does not differentiate between sons and daughters. Only daughters are analyzed by Shaw (1982). For them she finds a negative and significant absent-father effect that operates largely through parental income.

Less conventional is a test for role-model effects of the success of absent-but-active fathers. For this analysis we imputed father's income from regressions run on present fathers and included these imputed values in the education and ln wage regressions for children, allowing for tests of differential marginal income effects depending on whether the father was present. A variety of specifications were estimated, including adjustments for selection bias. These yielded the general conclusions that additional dollars of absent father's income have no positive effect on the outcomes for children, while the additional dollars of income of fathers who are present tend to have a positive influence. Thus, the success of the father is apparently relevant only when the father is present-a conclusion that is also consistent with the resource interpretation of the economic hypothesis.

Turning attention from fathers to mothers, there is a strong case for expecting bias in estimating the role model effect of mother's labor income from factors that influence her decision about participation in the labor force. Economic models of labor supply view the decision about paid employment as resting on a comparison of one's potential market wage and reservation wage, the latter determined primarily by the value of time spent in nonmarket activities such as childcare. Women who are unusually productive in providing childcare and other household services will be less likely to work at paid employment. At the same time, their children may benefit from their productivity by being able to complete more schooling or earn higher wages. This unusual productivity at home will produce a negative correlation between the error terms in the labor market selection equation and the child attainment equation.

A different kind of selection bias could arise if mothers who participate in the labor market have a stronger market orientation than mothers who do not. If the market orientation of a child is influenced by the market orientation of the mother, and the child's market orientation has a positive influence on his or her labor market-related attainments, then a positive correlation would exist between the error terms of the mother's labor force participation equation and the child attainment equation. Heckman's (1979) technique adjusts for both kinds of error correlation, provided the selection equation is properly specified. 
To adjust for the effects of nonworking mothers we first estimate a probit equation for whether or not a mother was working 250 or more hours each year when the child was age 14-16. ${ }^{21}$ This was followed by estimation of the child's education and In wage rate using the portion of the sample with working mothers and including controls from the firststage probit for the probability of having a working mother. As with the father role model, the most appropriate test of the mother role model hypothesis addresses the question of whether the effects of the labor income of the mother are significantly larger than the effects of other sources of income.

The results shown in Table 5 provide no support for the role model hypothesis for mothers, with the typical pattern being smaller coefficients on mothers' income than on income from sources other than parents' earnings. The coefficient on the lambda term is positive but insignificant in all cases, lending very weak support for the market orientation view of selection bias.

A final piece of evidence on father and mother role models comes from attainment equations estimated on the combined sample of sons and daughters that included the interaction of gender and parents' income. ${ }^{22}$ They failed to show stronger influences for father-son and motherdaughter pairs.

\section{Working Mother}

Reductions in the amount of parental supervision, assistance, socialization, and training are hypothesized to result when the mother works in the labor market, with the loss of supervision causing behavioral problems in school that may in turn lead to early departure from school and ultimately result in lower wages. One test of this hypothesis is to assess the impact of a mother's employment outside the home on her children's educational attainment and wages. Table 3 shows that the use of mother's labor income to identify working mothers provides mixed support for the hypothesis. Coefficients on the first dollar of mothers' labor income demonstrate the effect of a change from no outside employment to employment yielding a very low income. These coefficients

\footnotetext{
${ }^{21}$ The predictor variables included in this probit analysis are mother's education, number of children in household when child was age 15, age of youngest child in household when child was age 15 , asset income of parents, father's labor income, and mother's age when child was age 15 .

"A dummy variable of 0 for men and 1 for women was also added to allow for noninteractive effects of gender. The regressions produced the following coefficients (standard errors) on the gender-father's income interaction term, scaled in thousands: $-.002(.009)$ for educational attainment and $-.002(.003)$ for In wage. A separate analysis yielded these coefficients (standard errors) on the gender-mother's income interaction term, scaled in thousands: $-.034(.035)$ for educational attainment and $.008(.010)$ for In wage.
} 
are uniformly negative for children's educational attainment and wage rates, but significant at the .10 level at best.

However, a discrete indication of whether or not the mother is employed may not be the best indicator of the extent to which her supervisory time is reduced by market work. A better measure is the mother's work hours. Consequently, a supplemental set of regressions was run with the usual background control variables, total family income, and average work hours of the mother when the child was age 14-16. The results of these regressions, shown in the bottom panel of Table 5, provide consistent support for the theory that outside employment by mothers has a detrimental effect on the attainments of sons. ${ }^{23}$ Everything else equal, having a mother employed full-time as opposed to not at all was associated with a half-year less completed schooling and $14 \%$ lower wages. A check for possible interactions between mother's work hours and the absence of father revealed none.

Of course, everything else, especially family income, would not be equal if the mother were to reduce her work hours, so the positive effect of the reduction in work hours would be offset by the negative effect of a lower family income, with the extent of the latter a function of the mother's wage rate. Using the coefficients on total family income shown in the bottom panel of Table 5 as an indicator of the income effects, it can be seen that the income effect of reduction of 2000 work hours for a woman earning $\$ 5$ an hour would offset about two-thirds of the beneficial effect on sons' completed schooling and about half of the beneficial effect on sons' wage rates. There are also negative coefficients on mothers' work hours for both the educational attainment and ln wage rates of daughters, but the coefficients were smaller than those for sons and insignificant at conventional levels.

There is an enormous body of literature on the possible effects of working mothers (Hayes and Kamerman, 1983; Hoffman and Nye, 1974) but a much smaller one that focuses on outcomes such as completed schooling or wage rates and controls for parental income level. Our findings corroborate those of Datcher-Loury (1986), who finds with PSID data negative and significant effects of mothers' work hours on the completed schooling of sons but not daughters after controlling for both parental income and a crude measure of mother's childcare time, and

${ }^{23}$ An alternative interpretation, suggested by Gary Solon and a referee, is that in a regression such as this that controls for labor income, additional work hours are an inverse proxy for mother's wage rate. While there are reasons to believe that wage rates of mothers and children may be linked (e.g., through the teaching of labor market skills, connections), these links would seem likely to be stronger for daughters than sons. The opposite pattern appears in the data. In addition, the work hours measure includes many cases with zero values, the point at which wage rates are undefined, making the inverse work hours-wage rate relationship nonmonotonic. 
Stafford (1986), who finds with reinterview data from the 1975-1976 and 1980-1982 Time Use Surveys generally negative and significant effects of mother's work hours in 1975-1976 on the school performance of young children in 1980-1981. Stafford also controls for parental income and a well-measured set of childcare variables. Our findings are somewhat at odds with those of Alwin and Thornton (1984), who, after adjusting for parental income and background measures, find for their sample of white children living in intact families negative but insignificant effects of early and late maternal employment on completed education and with those of Sewell et al. (1980), who, with similar adjustments, find negative but insignificant effects of maternal employment on the attainment of daughters but positive and at times significant effects on the attainments of sons. D'Amico et al. (1983) conclude with NLS data that mothers' employment has no pervasive effect on the educational attainment or career paths of sons or daughters. Thus, our findings add to the variety of results.

\section{Welfare Culture}

The alleged damaging effects of contact with the welfare system are the basis for two simple hypotheses: that the first dollar and that subsequent dollars of receipt will have negative effects on the attainments of children. The data provide little support for either this view or the alternative view implicit in the economic models' assumption that welfare dollars are invested in children by their parents (Table 3). Two of the coefficients on the added dollars of welfare income are negative and two are positive, but none is significantly different at conventional levels from either zero or the pooled family income coefficient.

One of the four coefficients on the first dollar of welfare-for completed education of daughters-is statistically significant and negative. The fact that the corresponding added-dollar coefficient is not negative as well (in fact, it is positive and larger than its standard error) runs contrary to the welfare culture hypothesis that added dollars of welfare have detrimental effects. In sum, welfare receipt in the parental family appears neither to retard nor to augment significantly the socioeconomic attainments of children.

\section{Income as a Signal of Heterogeneity}

Confounding attempts to interpret the effects of income components on attainments is the possibility that receipt of certain kinds of income, especially from assets and welfare, is a signal of more important underlying characteristics of the family. These effects would show up as significant coefficients on the first dollars of income from those sources.

There is strong support regarding the heterogeneity hypothesis for completed education. Higher schooling levels are observed for sons and daughters raised in families with asset income. However, significant effects 
are not observed for wage rates, nor are there significant effects of additional dollars of asset income on the education of sons. Families with asset income may be better able to set and attain goals for their children's education, quite apart from the total amount of savings they have available for that purpose. These traits do not appear to translate into greater labor market success for the children of such families. Evidence on welfare heterogeneity is not as strong: as mentioned above, only one of the four first-dollar coefficients is significantly different from zero at conventional levels.

\section{SUMMARY}

We began our inquiry with empirical confirmation based on PSID data of what other researchers have found using different data: schooling and early career attainments of both sons and daughters are significantly affected by the income level of the parental family, even after one controls for a large set of other parental background measures. No single explanation of the link between parental income and children's attainment from either the economics or sociology literature received unambiguous support from the additional tests we performed. However, we can clearly differentiate among the various theories in the degree of support they did receive.

Two propositions received virtually no support in the data: the first is that labor market attainments of mothers serve as positive role models for daughters or sons. After adjusting for possible selection biases, we found that additional dollars of mothers' labor income generally had a less, rather than more, positive effect on the attainment of children than did income from other sources.

The second unsupported proposition was that receipt of welfare income had a detrimental effect on children. At worst, the effect of welfare dollars was negligible; at best, welfare dollars had the same positive effect as dollars from non-welfare sources. The low correlation between receipt of welfare when the child was between 14 and 16 with the longer run income level of the parental family may have rendered tests regarding the effects of welfare particularly imprecise.

The hypothesis receiving strongest support in the data concerned work hours rather than labor income. Sons completed significantly less schooling and earned significantly less the more their mothers worked while they were between the ages of 14 and 16. The schooling effect for sons is consistent with theories that posit developmental problems with sons if the mother spends a great deal of time outside the home. The empirical support for this theory must be qualified in three important ways, however: our data measured neither developmental nor certain crucial behavioral outcomes directly; we lacked information on the mother's labor force activity at other points in her son's or daughter's childhood; and the detrimental effects of work hours are offset to some extent by the beneficial 
effects of the income earned with those work hours. Nevertheless, the support that was accorded this hypothesis suggests that it should be the focus of additional attention in the intergenerational attainment litcrature.

Also receiving some support was the proposition from Becker's economic model that family income is invested in children without regard for its source. The null hypothesis of positive and comparable effects regardless of source could not be rejected for either of the attainment outcomes for daughters. It could be rejected for sons, as a result of the larger effect of fathers' income on the attainments of sons. This latter result is consistent with the father-son role model hypothesis. However, the significance levels for the father role model tests were marginal, there were effects for neither mother-daughter nor absent father-son pairs, and the high correlation between fathers' labor income and total childhood income may account for its added explanatory power. Based on our evidence alone, all of these considerations temper enthusiasm for the role model theory. Another point to keep in mind is that the teen years may not be the most appropriate part of childhood to test parental role model effects: the influence of peer groups and teachers may overwhelm that of parents during the later stage of childhood.

It is clear that we have only begun to explore the rich potential of the intergenerational data available in the PSID. Additional years of data, three waves of which have already been collected but were not yet available, will add substantially to its analytic potential for discriminating among the multitude of hypotheses concerning intergenerational transmission of economic status. Each added year can expand by about onethird the size of the sample used here, soon permitting important divisions of the sample, for example, along racial lines. Added years of data can also be used to measure labor market outcomes of children at older ages or the characteristics of parents when their children are younger. Expansion of the data in all three respects-sample size, further into adulthood and further back into childhood-will help shed light on the part parents' income plays in the economic attainments of their children. 


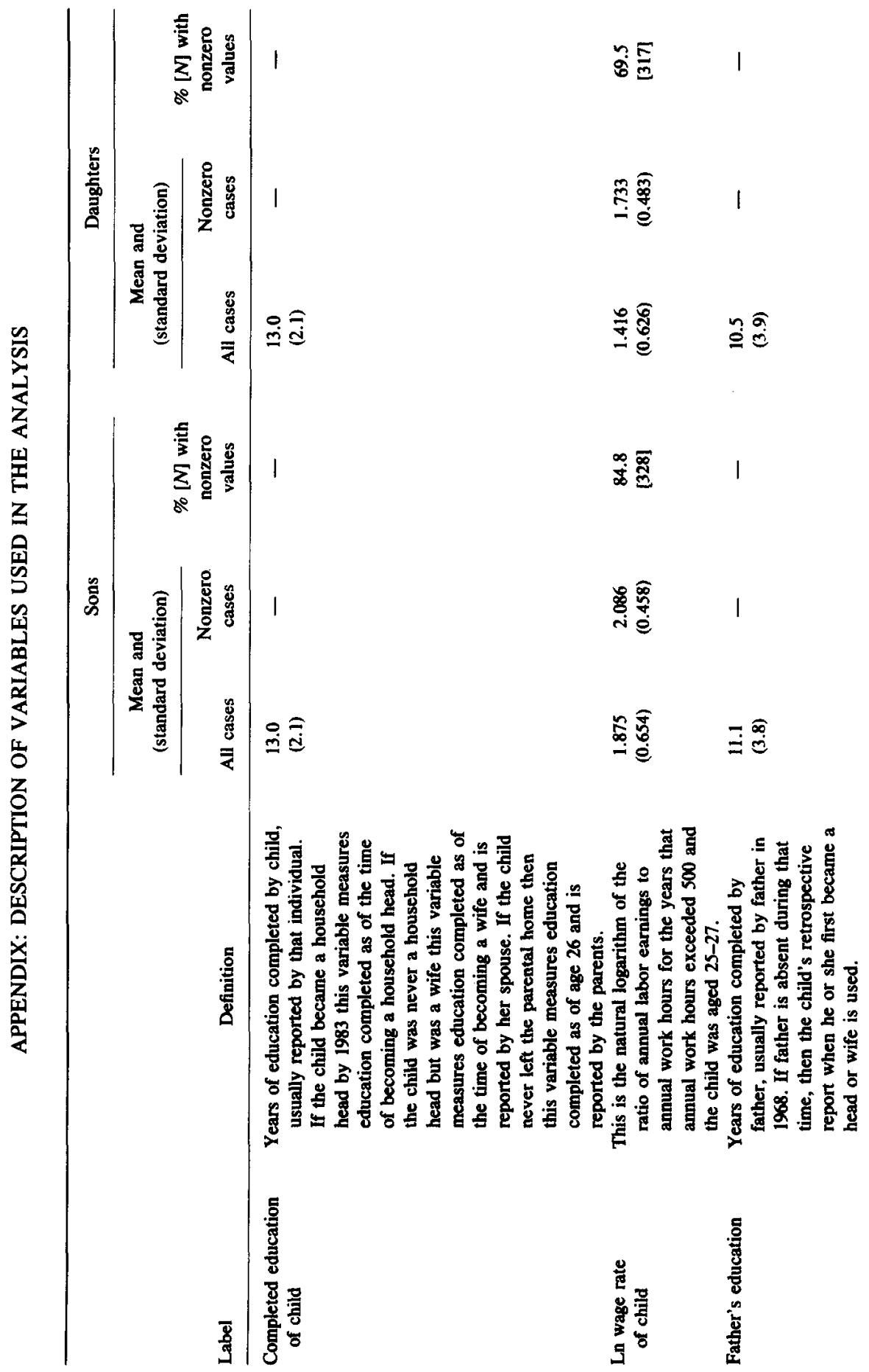




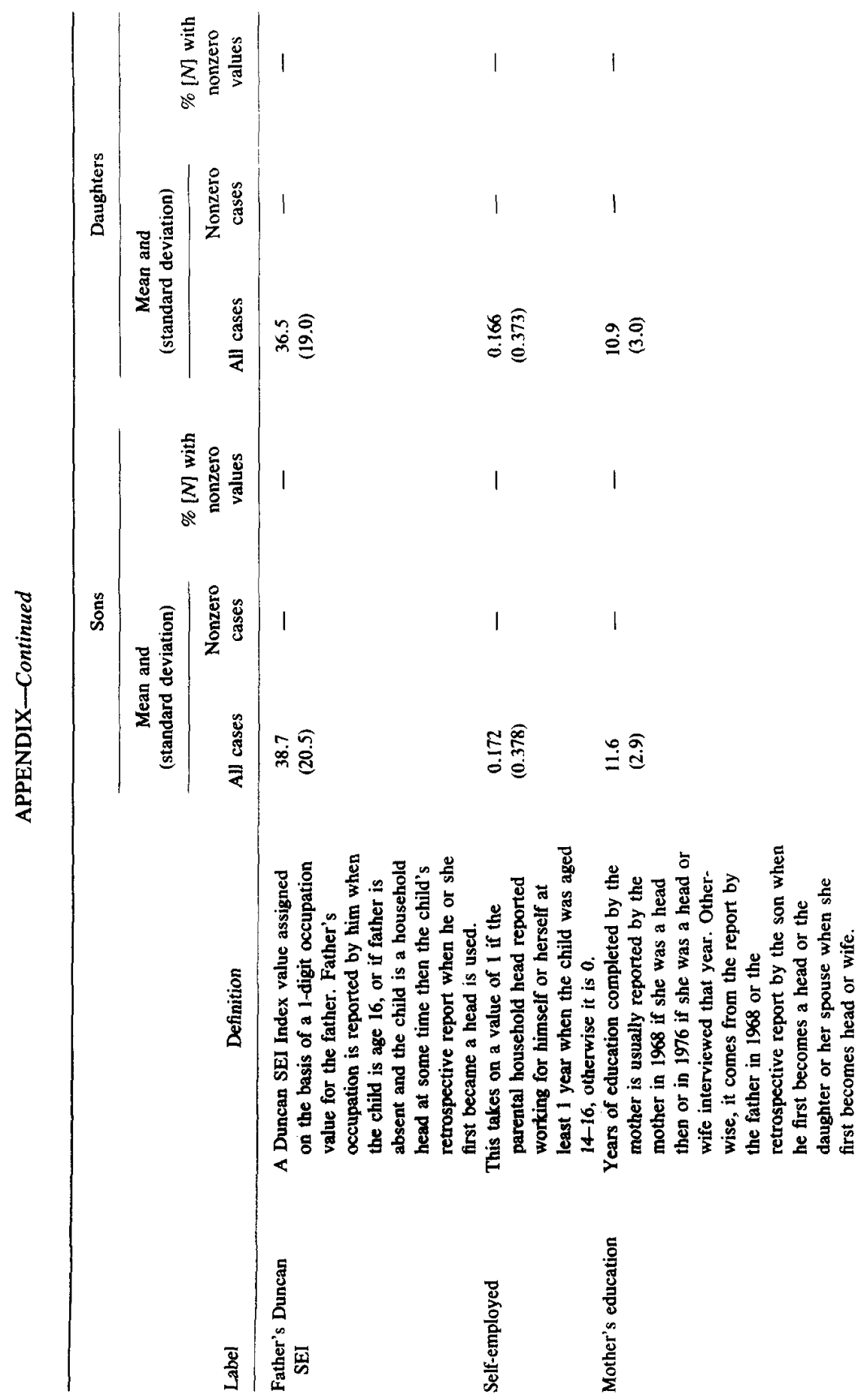




\begin{tabular}{|c|c|c|c|c|c|c|}
\hline 1 & 1 & 1 & 1 & 1 & 1 & 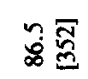 \\
\hline 1 & 1 & 1 & 1 & 1 & 1 & 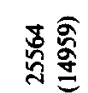 \\
\hline 표 & 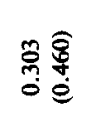 & 玩勇 & 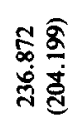 & $\stackrel{m}{\stackrel{F}{\hat{m}}}$ & 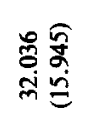 & 离 \\
\hline 1 & I & 1 & 1 & 1 & 1 & 品 \\
\hline 1 & 1 & 1 & 1 & 1 & 1 & कृत्d \\
\hline m & 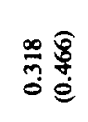 & 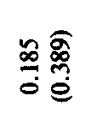 & 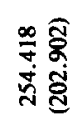 & : & 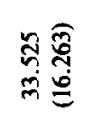 & 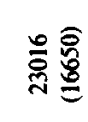 \\
\hline
\end{tabular}
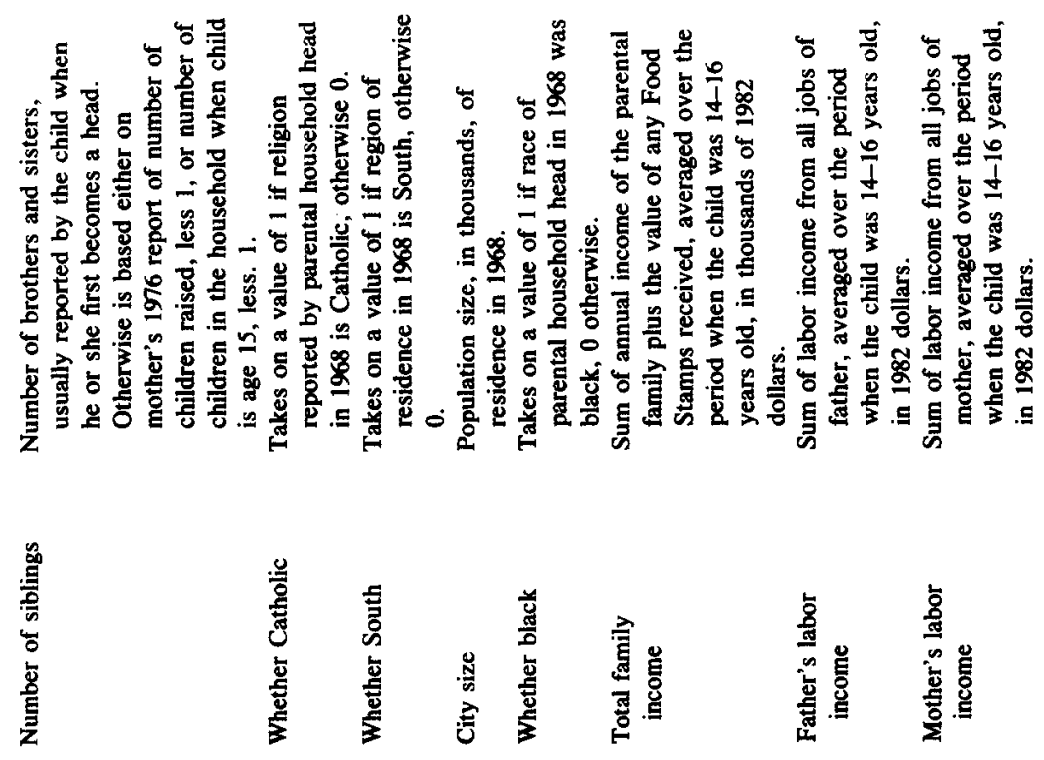


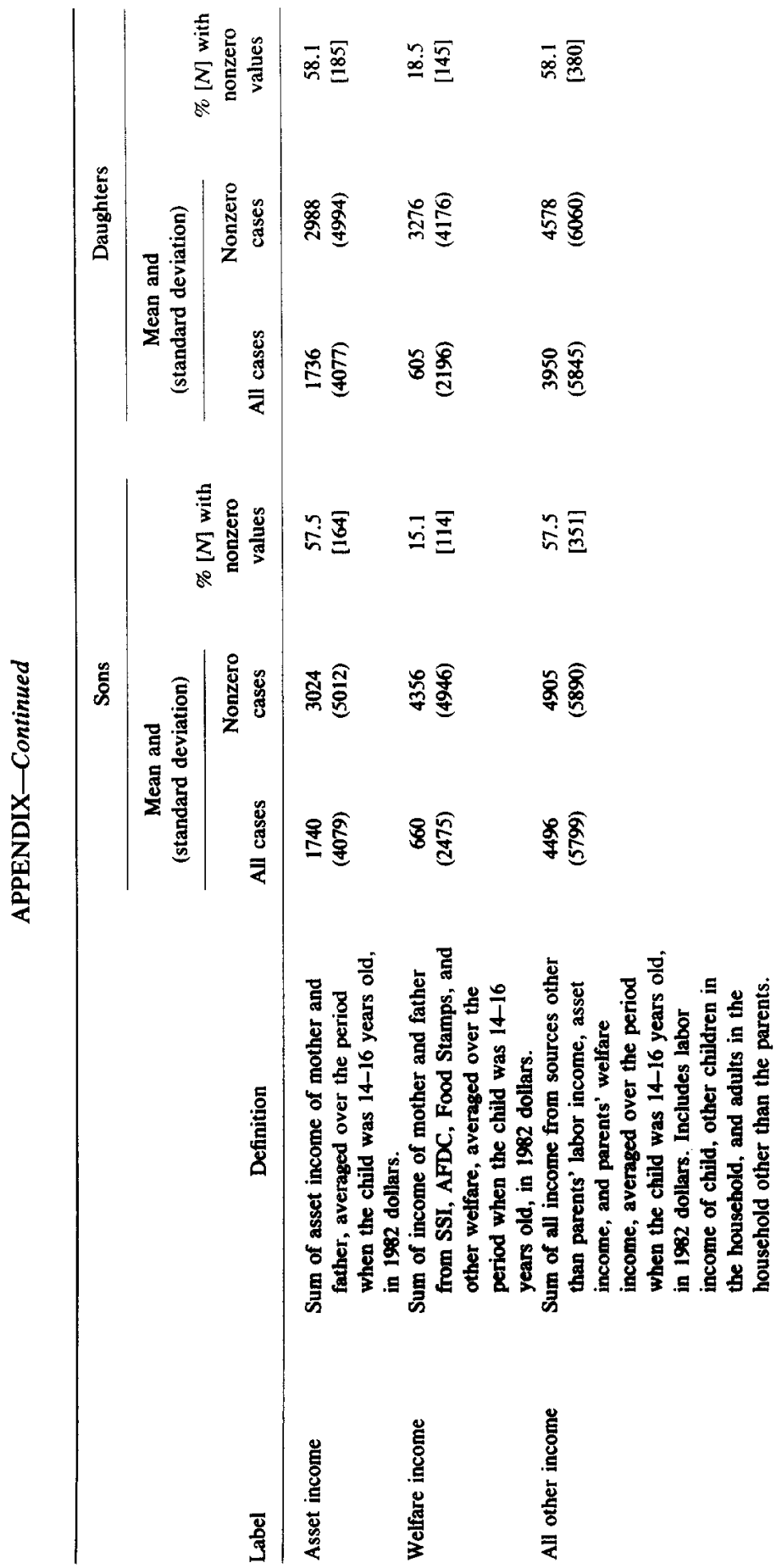




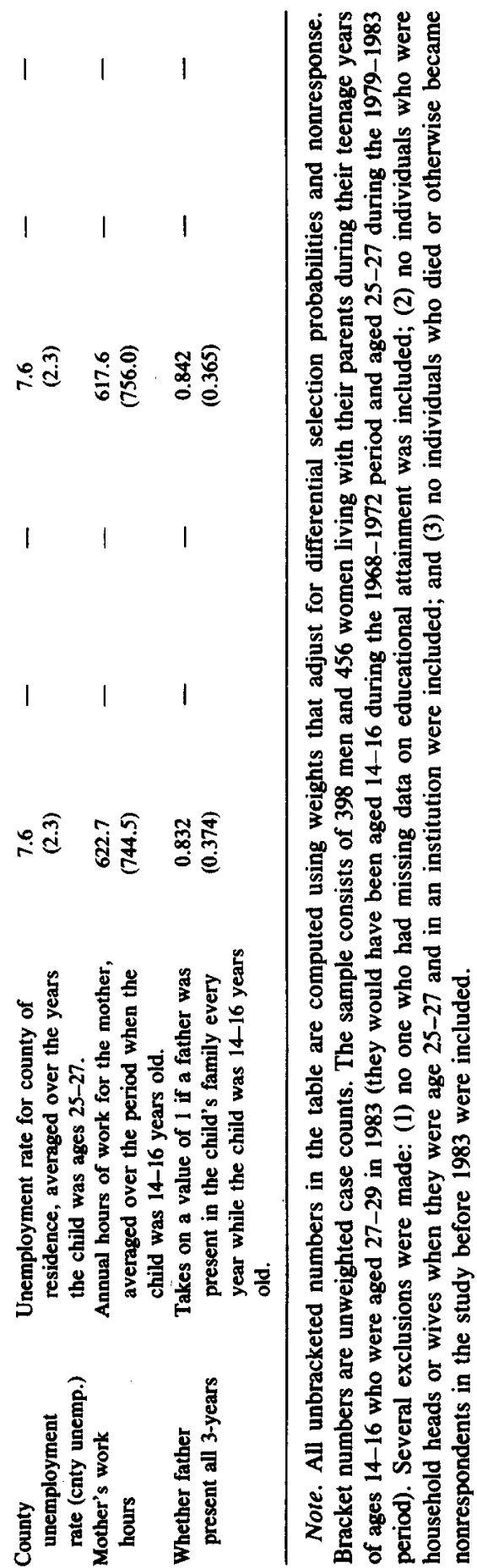




\section{REFERENCES}

Alwin, D. F., and Thornton, A. (1984). "Family origins and the schooling process," American Sociological Review 49(6), 784-802.

Bane, M. J., and Ellwood, D. (1983). "The dynamics of dependence and the routes to self-sufficiency," Final Report to the U.S. Department of Health and Human Services, Harvard University, Kennedy School of Government, Cambridge, Mass.

Becker, G. S. (1974). "A theory of marriage: Pt. II," Journal of Political Economy 82(2), 817-26.

Becker, G. S. (1981). A Treatise on the Family, Harvard Univ. Press, Cambridge, Mass.

Becker, G. S., and Tomes, N. (1979). "An equilibrium theory of the distribtuion of income and intergenerational mobility," Journal of Political Economy 87(6), 1153-1189.

Becker, G. S., and Tomes, N. (1986). "Human capital and the rise and fall of families," Journal of Labor Economics 4(3), S1-S39.

Behrman, J. R., Hruber, Z., Taubman, P., and Wales, T. J. (1980). Socioeconomic Success: A Study of the Effects of Genetic Endowments, Family Environment, and Schooling, North-Holland, New York.

Behrman, J., and Taubman, P. (1985). "Intergenerational earnings mobility in the United States: Some estimates and a test of Becker's intergenerational endowments model," Review of Economics and Statistics 67(1), 144-151.

Ben-Porath, Y. (1980). "The F-connection: Families, friends, and firms and the organization of exchange," Population Development Review 6(1), 1-30.

Bielby, W. T., and Hauser, R. M. (1977). "Response error in earnings functions for nonblack males," Sociological Methods and Research 6(2), 241-279.

Corcoran, M., and Datcher, L. (1981). "Intergenerational status transmission and the process of individual attainment," in Five Thousand American Families-Patterns of Economic Progress (M. S. Hill, D. H. Hill, and J. N. Morgan, Eds.), Survey Research Center, Ann Arbor, Mich.

D'Amico, R. J., Haurin, R. J., and Mott, F. L. (1983). "The effects of mothers' employment on adolescent and early adult outcomes of young men and women," in Children of Working Parents: Experiences and Outcomes (C. D. Hayes and S. B. Kamerman, Eds.), National Academy Press, Washington, D.C.

Datcher-Loury, L. (1986). Effects of Mother's Home Time on Children's Schooling, mimeo, Tufts University.

Duncan, B., and Duncan, O. D. (1969). "Family stability and occupational success," Social Problems 16, 273-283.

Hauser, R. M., and Daymont, T. N. (1977). "Schooling, ability, and earnings: Crosssectional findings 8 to 14 years after high school graduation," Sociology of Education 50, 182-206.

Hayes, C. D., and Kamerman, S. B., Eds. (1983). Children of Working Parents: Experiences and Outcomes, National Academy Press, Washington, D.C.

Heckman, J. (1979). "Sample selection bias as a specification error," Econometrica 47(1), 153-161.

Hetherington, E. M., Camara, K. A., and Featherman, D. L. (1983). "Achievement and intellectual functioning of children in one-parent households," in Achievement and Achievement Motives: Psychological and Sociological Approaches (J. Spence, Ed.), Freeman, San Francisco.

Hoffman, L. W., and Nye, F. I. (1974). Working Mothers, Jossey-Bass, San Francisco.

Ishikawa, T. (1975). "Family structures and family values in the theory of income distribution," Journal of Political Economy 83(5), 987-1008.

Jencks, C., Crouse, J., and Meuser, P. (1983). "The Wisconsin model of status attainment: A national replication with improved measures of ability and aspiration," Sociology of Education 56(1), 3-19. 
Kiker, B. F., and Condon, C. M. (1981). "The influence of socioeconomic background on the earnings of young men," Journal of Human Resources 16(1), 94-105.

Macaulay, J. (1977). "Stereotyping child welfare," Society, 47-51.

McLanahan, S. (1985). "Family structure and the reproduction of poverty," American Journal of Sociology 90, 873-901.

Pollak, R. A. (1985). "A transaction cost approach to families and households," Journal of Economic Literature 23(2), 581-608.

Ross, H. L., and Sawhill, I. V. (1975). Time of Transition: The Growth of Families Headed by Women, The Urban Institute, Washington, D.C.

Santrock, J. W. (1972). "Relation of type and onset of father absence to cognitive development," Child Development 43, 455-469.

Sewell, W. H., and Hauser, R. M. (1975). Education, Occupation, and Earnings: Achievement in the Early Career, Academic Press, New York.

Sewell, W. H., Hauser, R. M., and Wolf, W. C. (1980). "Sex, schooling and occupational status," American Journal of Sociology 86, 551-583.

Shaw, L. B. (1982). "High school completion for young women," Journal of Family Issues 3(2), 147-163.

Shinn, M. (1978). "Father absence and children's cognitive development," Psychological Bulletin 85(2), 295-324.

Stafford, F. P. (1986). Women's Work, Sibling Competition and Children's School Performance, mimeo, University of Michigan.

Tomes, N. (1981). "The family, inheritance, and the intergenerational transmission of inequality," The Journal of Political Economy 89(5), 928-958.

Woelfel, J., and Haller, A. O. (1971), "Significant others, the self-reflexive act and the attitude formation process," American Sociological Review 36, 74-87. 